\title{
CORRELATION BETWEEN ANTHROPOMETRIC MEASUREMENTS AND RISK OF ANEMIA AMONG RURAL COMMUNITY IN CANGKRINGAN, SLEMAN
}

\section{KORELASI PENGUKURAN ANTHROPOMETRI DAN RISIKO ANEMIA PADA MASYARAKAT PEDESAAN DI CANGKRINGAN, SLEMAN}

\author{
Dita Maria Virginia*), Fenty \\ Faculty of Pharmacy, Universitas Sanata Dharma, Campus 3 Paingan, Maguwoharjo, Depok, \\ Sleman, Yogyakarta, 55282
}

Received October 11, 2017; Accepted November 21, 2017

\begin{abstract}
Anemia has been detected on various age groups. Measurement of hemoglobin $(\mathrm{Hb})$ levels is a standard for deciding anemia conditions. The measurement requires certain costs, medical professional, and is invasive. People in rural areas need an economical, easy and simple examination to identify the risk of anemia. Anthropometric measurement is expected to be an appropriate measurement model for rural communities. The objective of the study is to obtain the best anthropometric measurement predictors for detecting anemia in rural communities. This was an observational study using a cross-sectional design. The inclusion criteria of the subjects of the study were residents of Cangkringan, who were between 40 and 60 years old. The subjects were chosen using random sampling cluster technique. The sample size was 100 respondents and was taken based on cluster. Descriptive analysis was used to determine the prevalence of anemia. Analysis the difference in proportion was conducted using Mann-Whitney. Correlation analysis was performed to determine the relationship between $\mathrm{Hb}$ levels and anthropometric measurements by using Spearman. The results showed that only 5\% of the subjects are in the status of anemia based on their Hb levels. There is a significant difference between Hb levels in the normal and obese groups based on the waist hip circumference ratios (WHR) $(p=0.002)$. The waist circumference has a weak correlation $(r=0.238, p=0.017)$ and WR has a moderate correlation $(r=0.483, p=0.000)$ with Hb levels. The results of this study are not appropriate in which central obese patients should be more at risk of anemia. This study concludes that there is a significant positive moderate correlation between anthropometry, which is the waist circumference parameters and WHR, to the Hb levels in rural communities.
\end{abstract}

Keywords: hemoglobin levels, anthropometry, rural areas

\begin{abstract}
ABSTRAK
Penyakit anemia dialami oleh berbagai kelompok usia. Pengukuran kadar hemoglobin $(\mathrm{Hb})$ merupakan standar untuk melihat kondisi anemia. Pengukuran tersebut memerlukan biaya, tenaga medis, serta bersifat invasif. Masyarakat pedesaan memerlukan pemeriksaan yang ekonomis, mudah, sederhana untuk melihat risiko anemia. Pengukuran antropometri diharapkan menjadi model pengukuran yang tepat bagi masyarakat pedesaan. Tujuan penelitian untuk memperoleh prediktor pengukuran antropometri yang paling baik untuk mendeteksi anemia pada masyarakat pedesaan. Penelitian ini merupakan observasional dengan desain potong lintang (cross-sectional). Kriteria inklusi subyek penelitian adalah penduduk Kecamatan Cangkringan yang berumur 40-60 tahun. Subyek penelitian dipilih menggunakan teknik kluster random
\end{abstract}


sampling. Besar sampel adalah 100 orang responden dan diambil berdasarkan kluster. Analisis deskriptif untuk menentukan prevalensi anemia. Analisis untuk melilhat perbedaan proporsi menggunakan Mann-Whitney. Analisis korelasi dilakukan untuk menentukan hubungan antara variabel bebas dan variabel tergantung dengan menggunakan Spearman. Hasil penelitian menunjukkan hanya 5\% subjek penelitian dalam status anemia berdasarkan kadar Hb. Terdapat perbedaan yang bermakna antara kadar Hb pada kelompok normal dan obesitas berdasarkan rasioa lingkar pinggang panggul (RLPP) $(p=0,002)$. Lingkar pinggang memiliki korelasi lemah $(r=0,238, p=0,017)$ dan RLPP memiliki korelasi sedang $(r=0,483, p=0,000)$ dengan kadar Hb. Hasil penelitian ini tidak sesuai dimana seharusnya pasien obesitas sentral lebih berisiko anemia. Penelitian ini menyimpulkan terdapat korelasi sedang positif yang bermakna antara antropometri, yaitu parameter lingkar pinggang dan RLPP, terhadap kadar hemoglobin pada masyarakat pedesaan.

Kata kunci: kadar hemoglobin, antropometri, pedesaan

\section{INTRODUCTION}

Anemia is one of the health problems in the world. Based on WHO surveys of 19932005 , the prevalence of anemia in the world has reached 1.62 billion and can be experienced by various age groups ranging from pediatric groups to geriatric groups. WHO data from 1993-2005 shows that some regions in Indonesia, including Bali, East Java and Bogor, have a high prevalence of anemia (WHO, 2008). National Health Survey (Riskesdas) conducted in 2013 showed that the national proportion of anemia in Indonesia was of $21.7 \%$ (Ministry of Health, 2013). A study in China showed that the population of anemia at the age between 40 and 60 years is of $35.3 \%$ and was increasing in the geriatric group age (> 60 years) (Zhai et al., 2010). This signifies the importance of conducting a study on the age range between 40 and 60 years so that the results of this study can be used for early detection.

Anemia is a condition of iron deficiency that can be detected through the hemoglobin (Hb) level (Zimmermann et al., 2008). Some international studies have shown that the prevalence of anemia is quite high in rural areas. The study of Alvarez-Uria et al. (2014) in India showed an increasing prevalence of anemia in rural areas which increases with age. Another study in Karnataka Village by Baliga et al. (2014) showed that $3 / 4$ subjects of the study had anemia. Studies on the number of anemia cases in rural areas of Indonesia have not been widely published and the results of Riskesdas in 2013 did not show the data as well. This underlies the need to look at the data of the prevalence of anemia in rural areas in this study.

Generally, communities in rural areas do not have access to adequate medical examinations either due to the lack of medical professional or economic factor, including in Indonesia (WHO, 2008; Bailey, 2009). WHO data in Indonesia showed that the implementation of health technology in rural areas is difficult to conduct because of the lack of medical professionals and economic problems (WHO, 2008). This is one of the causes of the difficulty to examine the $\mathrm{Hb}$ levels as a factor of anemia in rural areas. Anthropometric measurements are necessary for early detection of anemia risk factors especially in rural areas. Anthropometric measurements have several advantages for detecting a disease which are non-invasive methods, no requirements of attending medical professionals at the time of the measurement, and affordable costs. Anthropometric measurements have several criteria including body mass index (BMI), waist circumference (WC), hip circumference, waist and hip circumference ratio (WHR), arm circumference, skinfold thickness, and body fat percentage (BFP) (Bhowmik et al., 2009).

Anthropometric measurement studies have been widely conducted internationally (especially BMI) and show a significant 
correlation between anthropometric measurements and risk of anemia (Chang et al., 2014; Hausman et al., 2011; Saxena et al., 2011). However, studies in Indonesia related to anthropometry and anemia have not been conducted. One of the studies found only showed that women with anemia had lower BMI, WC, and hip circumference (Briawan and Hardiansyah, 2010). Thus, this study is needed to observe other anthropometry parameters in relation to the correlation with anemia.

Therefore, it is necessary to do a similar study which is about the correlation of anthropometric measurements to the risk of anemia in rural areas. The target findings of this study are predictive measurement of anemia in Indonesia through simple anthropometric measurements, without the need for expert assistance, and non-invasive as well as economical for the rural communities in particular.

\section{METHODS}

This was an analytical observational study using a cross sectional design. This study observed about correlation between BMI, waist circumference (WC), waist hip ratio (WHR), and body fat percentage (BFP) on $\mathrm{Hb}$ level (anemia status). The subjects of this study were the residents of Cangkringan, Sleman, D.I. Yogyakarta. The inclusion criteria of the subjects of the study were residents of Cangkringan who were between 40 and 60 years old. The exclusion criteria include patients who refused to take blood samples. The subjects of the study would be selected using a random sampling cluster technique. The sample size was 100 which was calculated based on the population proportion ( $\mathrm{P}=50 \%)$, confidence level $(90 \%)$, confidence interval (10\%), design effect $(2 \%)$ and attrition rate $(15 \%)$.

The instruments used were stationery and questionnaire to record the identity of subjects; weight scales, height gauges, skinfold gauge to perform the anthropometric measurements. The weight scales, height and skinfold gauge have been previously calibrated. Hemoglobin measurement was conducted using the Cobas C581® tool. BMI is the calculation results of body weight $(\mathrm{kg}) /$ (height) (m) $\mathrm{x}$ height (m)), WHR is the ratio of waist circumference / hip circumference, and BFP is the measurement of skin folds from 3 points of the body that are on the suprailliac, abdomen, and triceps. Anthropometric parameters are categorized as presented in Table I.

A preliminary study was conducted and a random sampling was carried out for the study. The first step was obtaining the permit of the study from the bureaucracy in Bappeda office of Sleman Regency. The ethical clearance was obtained from the Faculty of Medicine of Gadjah Mada University. The participation of the subjects of the study was based on a voluntary basis by first signing the informed consent. The study started by interviewing the patients in relation to their identity, weight measurement, height measurement and continued by collecting the patients' laboratory data by the analysts. The laboratory data collected were in the form of hemoglobin levels. The descriptive analysis was conducted to determine the prevalence of anemia and the characteristics of respondents. Normality test was conducted using Kolmogorov Smirnov and the results showed that almost all data were not normally distributed ( $\mathrm{p}<0.05$ ); only the BFP and the $\mathrm{Hb}$ levels were normal. A comparative analysis to observe the difference in proportion between anthropometric parameters and mean of $\mathrm{Hb}$ was conducted using Mann-Whitney. The correlation analysis to observe the relationship between anthropometry and $\mathrm{Hb}$ levels was conducted using Spearman.

\section{RESULTS AND DISCUSSION}

In this study, only 5 respondents experienced anemia. That is the reason why the data analysis and discussion will give more emphasis on the $\mathrm{Hb}$ issue, not the status of anemia experienced. Only 5\% of the population is included in the anemia status because the subjects of the study live in mountainous areas. People who live in the plateau or in the mountainous areas have higher $\mathrm{Hb}$ levels than the people in the 
lowlands. This is due to the low oxygen pressure on the plateau so the body compensates with the increase in hemoglobin which enables the body to bind more $\mathrm{O}_{2}$. This becomes a separate note for the subsequent study to assess the anemia status not only based on $\mathrm{Hb}$ levels but also $\mathrm{Fe}$ levels (Windsor and Rodway, 2007).

Table II shows the characteristics of all respondents of the study. In Table II, 78\% of the respondents are between 41 and 50 years old, most of them have a normal anthropometry as seen from BMI (53\%), waist circumference $(63 \%)$ and BFP $(81 \%)$. However, if it is seen from the WHR, $52 \%$ of the respondents are including on obese condition. The mean value of BMI and WHR parameters show that both female and male respondents are in obese condition.

Table III shows that the BMI does not show significant difference between hemoglobin levels in BMI group $<25 \mathrm{~kg} / \mathrm{m} 2$ and $>25 \mathrm{~kg} / \mathrm{m} 2 \quad(\mathrm{p}=0.153)$. In addition, Hemoglobin levels do not differ significantly between the normal anthropometric group and the obese group based on the WC parameter $(p=0.491)$ and BFP $(p=0.847)$. The Whr parameter is the only anthropometric parameter showing a significant proportion of difference between $\mathrm{Hb}$ levels in the normal WHR group with the WHR group that show obesity with $p=0.002$. Since it is inconclusive, this study will continue with Spearman test to determine the direction of the correlation between WHR and $\mathrm{Hb}$ level. Results from median values show that the obese group based on BMI, WHR, and BFP has higher $\mathrm{Hb}$ levels than the normal group.

The results of the study show no correlation between BMI and BFP on the hemoglobin level $(p>0.05)$. The absence of correlation between BMI and hemoglobin levels is consistent with previous studies suggesting that obesity with BMI parameters did not show differences between the obese and the normal groups towards the $\mathrm{Hb}$ levels, but the study was specific to anemia in chronic disease (Ausk and Ioannou, 2008). A study in Nigeria by Ugwuja et al. (2015) also showed similar results in the absence of correlation between BMI and anemia. However, there are studies showing that there is a negative correlation of BMI to anemia in female students categorized in the overweight and obesity status (Saxena et al., 2011). The absence of a correlation between BFP and $\mathrm{Hb}$ levels is similar to a study on adolescent subjects where anemia was not correlated with BMI and BFP. However, in general, obesity remained correlated with low levels of $\mathrm{Hb}$ (Bagni et al., 2013).

Table I. Anthropometric Parameters

\begin{tabular}{ll}
\hline $\begin{array}{c}\text { Anthropometric } \\
\text { Parameters }\end{array}$ & Obesity Status Category \\
\hline BMI & Normal value of non-obesity if BMI $<25 \mathrm{~kg} / \mathrm{m} 2$ \\
\hline WC & $\begin{array}{l}\text { According to International Diabetes Foundation, ideal waist circumference is at: } \\
\text { Female }<80 \mathrm{~cm} \\
\\
\text { Male }<90 \mathrm{~cm}\end{array}$ \\
\hline WHR & The results of waist circumference divided by hip circumference \\
& Metabolic risk increases when male $\geq 0.90$ and female $\geq 0.85$ \\
\hline BFP & Normal value of non-obesity: \\
& Female $25-30 \%$ \\
& Male $18-25 \%$ \\
\hline
\end{tabular}


Table II. Respondents Characteristics

\begin{tabular}{|c|c|c|c|c|}
\hline Variable & $\begin{array}{l}n(\%) \\
n=100\end{array}$ & $\begin{array}{c}\text { Mean } \\
(95 \% \mathrm{CI})\end{array}$ & Median & p (normality) \\
\hline \multicolumn{5}{|l|}{ Age (year old) } \\
\hline $40-50$ & $78(78)$ & 47.26 & 46.00 & 0.000 \\
\hline $51-60$ & $22(22)$ & $(46.12-48.39)$ & & \\
\hline \multicolumn{5}{|l|}{ BMI $\left(\mathrm{kg} / \mathrm{m}^{2}\right)^{*}$} \\
\hline$<25$ & $53(53)$ & 25.37 & 24.75 & 0.014 \\
\hline$\geq 25$ & $47(47)$ & $(24.50-26.23)$ & & \\
\hline \multicolumn{5}{|l|}{ Waist Circumference $(\mathrm{cm})$} \\
\hline -normal & $63(63)$ & 83.04 & 81.35 & 0.008 \\
\hline -obese & $37(37)$ & $(80.82-85.26)$ & & \\
\hline \multicolumn{5}{|l|}{ RLPP } \\
\hline -normal & $48(48)$ & 0.91 & 0.16 & 0.000 \\
\hline - obese & $52(52)$ & $(0.88-0.94)$ & & \\
\hline \multicolumn{5}{|l|}{ BFP** } \\
\hline -normal & $81(81)$ & 23.30 & 23.05 & $0.200^{*}$ \\
\hline - obese & $19(19)$ & $(22.18-24.42)$ & & \\
\hline \multicolumn{5}{|l|}{ Hemoglobin level $* * *$} \\
\hline 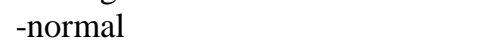 & $5(5)$ & 14.92 & 15.00 & $0.200 *$ \\
\hline -anemia & $95(95)$ & $(14.59-14.24)$ & & \\
\hline \multirow{2}{*}{\multicolumn{5}{|c|}{$\begin{aligned} \text { Note: } & * \text { normally distributed but false } \\
& * * \text { normal BFP value: female } 25-30 \% \text { and male } 18-25 \% \\
& * * * \text { Male is anemic if } \mathrm{Hb}<13 \mathrm{~g} / \mathrm{dL} \text { and female is anemic if }<12 \mathrm{~g} / \mathrm{dL}\end{aligned}$}} \\
\hline & & & & \\
\hline \multicolumn{5}{|c|}{ Table III. Differences in the Proportion of Hemoglobin Levels to Anthropometric Parameters } \\
\hline \multirow[t]{2}{*}{ Anthropometric Parameters } & \multirow{2}{*}{\multicolumn{3}{|c|}{$\begin{array}{c}\text { Hemoglobin level (mg/dL) } \\
\text { Median (minimum - maximum) }\end{array}$}} & $\mathrm{p}$ \\
\hline & & & & \\
\hline \multicolumn{5}{|c|}{ b } \\
\hline$<25 \mathrm{~kg} / \mathrm{m}^{2}$ & & 0.153 \\
\hline$\geq 25 \mathrm{~kg} / \mathrm{m}^{2}$ & \multicolumn{3}{|c|}{$15.50(10.80-18.70)$} & \\
\hline \multicolumn{4}{|l|}{ Waist Circumference } & \\
\hline Normal & \multicolumn{3}{|c|}{$15.10(9.50-18.70)$} & 0.491 \\
\hline Obese & & $14.60(10.80-17$. & & \\
\hline \multicolumn{4}{|l|}{ RLPP } & \\
\hline Normal & \multirow{2}{*}{\multicolumn{3}{|c|}{$\begin{array}{c}14.35(10.80-17.40) \\
15.75(9.50-18.70)\end{array}$}} & $0.002 *$ \\
\hline Obese & & & & \\
\hline \multicolumn{4}{|l|}{ BFP } & \\
\hline Normal & \multirow{2}{*}{\multicolumn{3}{|c|}{$\begin{array}{c}14.90(9.50-18.70) \\
15.40(12.70-17.40)\end{array}$}} & 0.847 \\
\hline Obese & & & & \\
\hline
\end{tabular}

Note: * there is a significant difference in proportion

Table IV. Correlation between Anthropometric Measurements and Haemoglobin Level

\begin{tabular}{lcc}
\hline Anthropometric Parameters & \multicolumn{3}{c}{ Hemoglobin Level } \\
\cline { 2 - 3 } & $\mathrm{r}$ & $\mathrm{p}$ \\
\hline BMI & 0.094 & 0.354 \\
\hline Waist Circumference & 0.238 & $0.017^{*}$ \\
\hline RLPP & 0.483 & $0.000^{*}$ \\
\hline BFP & -0.158 & 0.116 \\
\hline
\end{tabular}

Note: *statistically significant correlation

Table IV shows that WC and WHR are correlated with hemoglobin levels. WC $(\mathrm{r}=0.238, \mathrm{p}=0.017)$ and WHR $(\mathrm{r}=0.483$, $\mathrm{p}=0.000$ ) correlated weakly to the hemoglobin level with positive correlation direction. It can be concluded that the larger the WC and WHR, the higher the Hb level will be. The WC correlates weakly to the hemoglobin level with positive correlation. It can be concluded that the larger the WC, the higher the Hb level 
will be. The results of this study do not match with the study on the females in India that concluded that the central obesity group based on the WC is more at risk of anemia (Hemamalini, 2013).

The results of this study show a difference in $\mathrm{Hb}$ levels between the obese respondents and the normal respondents based on the WHR measurements. The hip waist circumference ratio (WHR) reflects abdominal obesity and is more often associated with cardiovascular risk. There are only few studies that discuss the WHR relationship to anemia in detail. Several studies have reported that females with central obesity who are reflected by WHR have an increased risk of anemia. This study shows that the WHR has a moderate positive correlation to $\mathrm{Hb}$ levels. This means that the higher the WHR (the risk of abdominal obesity), the higher the $\mathrm{Hb}$ levels are. Therefore, the results of the study are not in accordance with the studies that have been done previously (Qin et al., 2013; Gartner et al., 2013).

This study measures the correlation so that perhaps at a certain point, the high number of WC and / or WHR will reach a saturation point against the $\mathrm{Hb}$ level considering the weak correlation. Therefore, obesity subjects will not necessarily reduce the risk of anemia. Table III also shows that the median of the obese group has lower Hb levels than the normal group. This may mean that the higher the waist circumference and RLPP to the optimum limit, the higher the Hb levels. Further studies to see the optimal value are needed. Sinha and Haldar's study (2015) suggests that increased waist circumference and WHR are assumed to have a good nutritional intake so as to increase the $\mathrm{Hb}$ levels. However, the cardiovascular risk should also be noted.

A study in China by Qin et al. (2013) concluded that in China, females with obesity/overweight or central obesity are more likely to have anemia than the female subjects with normal anthropometry. This especially increased in older patients. The results of the study on female students show a significant difference between the BMI, BFP, and WHR values in the anemia group and non-anemia group. Supporting data suggest that low physical activity of female students increases the risk of obesity and low oxygen absorption, thus lowering serum oxygen levels resulting in decreased hemoglobin levels (Mohamed and Alhessain, 2012).

So far, the studies that have been done about the correlation of anemia to obesity are actually anemia with Fe levels measurement. Obesity which is an excess of nutrient and calorie intake will affect homeostasis in adipose tissue, liver, and iron homeostasis; obesity also reduces the absorption of $\mathrm{Fe}$ in the small intestine (Zimmermaann et al., 2008; Aigner and Datz, 2014). Anemia is more affected by eating style, age, and gender. The economic status also affects the anemia condition because the economic status will also affect nutrient intake (Alvarez-Uria et al., 2014; Gartner et al., 2013).

Other factors that can affect anemia are eating style, food type, location of residence, education level, and economic status. This study was conducted in Cangkringan which is a plateau so it enables the risk of bias. People who live on a plateau have lower oxygen need than people who live in lowlands so that the $\mathrm{Hb}$ levels may decrease according to the serum oxygen levels (Ugwuja et al., 2015; Mohamed and Alhessain, 2012).

\section{CONCLUSION}

Increased WC and WHR will decrease the risk of anemia if seen from Hb levels, in which WHR correlation to $\mathrm{Hb}$ levels is higher than the WC, and both have weak correlational strength. Further studies are needed to see the boundary of WC and WHR to $\mathrm{Hb}$ levels, the influence of other factors on $\mathrm{Hb}$ levels such as socioeconomic factors as well as eating style. Other parameters besides hemoglobin such as iron also need to be examined to predict the condition of anemia.

\section{ACKNOWLEDGEMENT}

This study was conducted as a research grant for novice researchers by KOPERTIS region $\mathrm{V}$ and assistance from Institute of 
Research and Community Service (LPPM) Universitas Sanata Dharma.

\section{REFERENCES}

Aigner, E., Feldman, A., Dat $z$, C., 2014. Obesity as an Emerging Risk Factor for Iron Deficiency. Nutrients, 6(9), 35873600.

Alvarez-Uria G., Naik PK, Midde M, Yalla PS, dan Pakam R., 2014. Prevalence and Severity of Anemia Stratified by Age and Gender in Rural Area. Anemia, http://dx.doi.org/10.1155/2014/176182

Ausk K.J., Ioannou G., N., 2008. Is Obesity Associated With Anemia of Chronic Disease? A Population-based Study. Obesity, 16, 2356-2361.

Bagni, U. V., Luiz, R. R., Veiga, G. V., 2013. Overweight is associated with low hemoglobin levels in adolescent girls. Obesity Research \& Clinical Practice, 7(3), 218-229.

Bailey, J.M., 2009. The Top 10 Rural Issues for Health Care Reform. CHFA (online), www.chfa.org accessed 15 April 2014.

Baliga, S.S., Naik, V.A., Mallapur, D.M., 2014. Nutritional status of adolescent girls residing in rural area: A community-based cross-sectional study. Journal of the Scientific Society, 41(1), 22-25.

Bhowmik, B., Munir, S.B., Diep, L.M., Siddiquee, T., Habib, S.H., Samad, M.A., Hussain, A., 2013. Antropometric Indicators of Obesity for Identifying Cardiometabolic Risk Faktors in A Rural Bangladeshi Population. Journal of Diabetes Investigation, 4(4), 361-368.

Briawan, D., Hardinsyah, H., 2010. Faktor risiko non makanan terhadap kejadian anemia pada

perempuan subur (15-45 tahun) di Indonesia. Jurnal Penelitian Gizi dan Makanan, 33(2), 22-28.

Chang, J., Chen, Y., Owaga, E., Palupi, K.C., Pan, W., Bai, C., 2014. Interactive effects of dietary fat/carbohydrate ratio and body mass index on iron deficiency anemia among Taiwanese women. Nutrients, 6, 3929-3941.
Gartner, A., Ati, J.E., Traissac, P., Bour, A., Berger, J., Landais, E., El Hsaïni, H., Ben Rayana, C., Delpeuch, F., 2013. A Doubel Burden of Overall or Central Odiposity and Anemia or Iron Deficiency Is Prevalent but with Little Socioeconomic Patterning among Moroccan and Tunisian Urban Women. The Journal of Nutrition, doi: 10.3945/jn.113.178285.

Hausman, D.B., Johnson, M.A., Davey, A., Poon, L.W., 2011. Body Mass Index is associated with dietary patterns and health conditions in Georgia Centenarians. Journal of Aging Research, doi:10.4061/2011/138015.

Hemamalini J., 2013. Anemia in Relation to Body Mass Index and Waist Circumference among Adhra Pradesh Women. Obes Weight Loss Ther., 3(3), 173-189.

Kementerian Kesehatan, 2013. Riset Kesehatan Dasar 2013.

Mohamed S., Alhessain, A., 2012. Anemia and Body Composition. International Journal of Science and Research, 3(5), 935-941.

Qin, Y., Melse-Boonstra A., Pan, X., Yuan, B., Dai, Y., Zhao, J., Zimmermann, M.B., Kok, F.J., Zhou, M., Shi, Z., 2013. Anemia in relation to body mass index and waist circumference among Chinese women. Nutrition Journal, 12(10), 1-3.

Saxena, Y., Shrivastava, A., Saxena, V., 2011. Effect of gender on correlation of anemia with body mass index in medical students. Indian J Physiol Pharmacol., 55(4), 364-369.

Sinha, N.K., Haldar, J.P., 2015. Correlation between Hemoglobin Level and Anthropometric Variables: A Study on Women of Reproductive Age Group, West Bengal. Anthropologist, 19(1), 185-192.

Ugwuja, I.U., Ogbonnaya, L.U., Obuna, A.J., Awelegbe, F., Uro-Chukwu, H., 2015. Anaemia in Relation to Body Mass Index (BMI) and Socio-Demographic Characteristics in Adult Nigerians in 
Ebonyi State. Journal of Clinical and Diagnostic Research, 9(1), 4-7.

Windsor, J.S., Rodway, G.W., 2007. Heights and hematology: the story of hemoglobin at altitude, Postgrad Med J., 83(977), 148-151.

World Health Organization, 2008. Global anemia prevalence and number of individuals affected. WHO (Online). http://www.who.int/vmnis/anaemia/prev alence/summary/anaemia_data_status_t2 /en/ accessed 15 April 2015.

World Health Organization, 2008. WHO Country Cooperation Strategy 20072011. WHO (Online) http://www.who.int/countryfocus/cooper ation_strategy/ccs_idn_en.pdf accessed 15 April 2015.

Zhai, Y., Yin, Z.X., Xu, J.W., Zeng, Y., Liu, Y.Z., Shi, S.M., 2010. Anemia status and its relevant factors among elderly people aged above 80 years old in longevity areas in China. Zhonghua $Y u$ Fang Yi Xue Za Zhi, 44(2), 115-118.

Zimmermann, M.B., Zeder C., Muthayya S., Winichagoon P., Chaouki N., Aeberli I., Hurrell R.F., 2008. Adiposity in women and children from transition countries predicts decreased iron absorption, iron deficiency and a reduced response to iron fortification. Int. J. Obes., 32, 1098-1104. 